\title{
LAYANAN BIMBINGAN KARIER UNTUK MENGEMBANGKAN PERENCANAAN KARIER SISWA SMA
}

\author{
Shidratul Attika \\ Email: shidratulattikaa@gmail.com
}

\begin{abstract}
Abstrak
Usia remaja adalah usia di mana individu sudah mulai mempersiapkan karier masa depan. Oleh karena itu, individu harus memiliki pengetahuan dan kemampuan atas karier yang akan dipilih. Karier yang dipilih seyogianya sesuai dengan potensi dan minat yang ada di dalam diri masing-masing individu. Individu yang masuk kategori usia remaja pada jenjang Sekolah Menengah Atas sebaiknya mulai merencanakan karier. Perencanaan karier penting bagi siswa SMA agar tidak salah dalam mengambil keputusan karier nantinya. Untuk membantu siswa dalam merencanakan karier, diperlukan layanan bimbingan karier di sekolah, di mana bimbingan karier adalah salah satu layanan bimbingan dan konseling untuk membantu siswa memahami dirinya serta memilih karier sesuai dengan potensi dan minatnya. Layanan ini juga bertujuan agar siswa dapat menentukan studi lanjutan yang akan dipilih sehingga karier yang akan dicapai tepat dan sesuai dengan potensi yang dimilikinya. Penulisan artikel ini merupakan kajian literatur. Dengan dilaksanakannya bimbingan karier di sekolah diharapkan siswa mampu memaksimalkan potensi untuk bersaing di era globalisasi. Hal ini berguna sebagai aspek pendukung bagi siswa dalam meraih kesuksesan kariernya.
\end{abstract}

Kata kunci: Bimbingan karier; perencanaan karier; siswa SMA

\section{PENDAHULUAN}

Persiapan dalam menentukan karier harus dilakukan dengan baik, oleh karena itu siswa khususnya yang berada pada kategori usia remaja (jenjang Sekolah Menengah Atas) seyogianya telah memiliki perencanaan akan studi lanjutan atau pekerjaan yang akan dipilihnya. Persiapan ini dilakukan agar siswa dapat merencanakan karier sesuai dengan potensi dan minat yang dimilikinya.

Karier didefinisikan sebagai serangkaian sikap, aktifitas, atau perilaku yang diasosiasikan dengan peran sepanjang kehidupan seseorang (Arthur \& Lawrence, dalam Pratama \& Suharnan, 2014). Super (dalam Sukardi, 1989) mendefiniskan karier sebagai suatu rangkaian pekerjaan, jabatan dan kedudukan yang mengarah pada 
kehidupan dalam dunia kerja. Karier merupakan suatu keseluruhan kehidupan seseorang dalam perwujudan diri untuk menjalani hidup dan mencapai tujuan. Untuk mencapai tujuan tersebut, individu harus memiliki kekuatan yang dimiliki seperti penguasaan kemampuan dan aspek yang menunjang kesuksesan karier. Dari penjelasan yang telah diuraikan dapat disimpulkan bahwa karier adalah aktifitas yang berhubungan dengan perkerjaan yang dijalani oleh seseorang semasa hidupnya, yang memerlukan keahlian yang sesuai agar tercapai tujuan karier yang diinginkan. Menjalani karier juga merupakan salah satu proses bagi individu untuk terus mengembangkan potensi dan kemampuan yang ada pada dirinya.

Masa remaja diidentifikasi sebagai tahap ketika proses pembentukan identitas karier dimulai (Crocetti \& Meeus, dalam Xu \& Lee, 2017). Terdapat kesepakatan umum bahwa masa remaja adalah masa yang penting untuk mengeksplorasi minat kejuruan dan membuat keputusan yang akan memengaruhi perkembangan karier. Istilah seperti kristalisasi dan persiapan karier sering digunakan dalam membentuk tujuan pekerjaan dan kesiapan untuk membuat keputusan terkait karier tertentu (Hirschi, dalam Xiao, dkk, 2016).

Tugas perkembangan karier yang penting untuk remaja khususnya siswa SMA adalah mengenali minat, kapasitas, dan nilai; mencari dan memperoleh pengetahuan tentang pekerjaan; dan akhirnya memutuskan jalur pendidikan dan karier yang realistis. Ketika membuat keputusan mengenai karier, siswa juga perlu menerapkan sikap dan perilaku karier yang positif dan didasarkan pada keputusan mereka tentang pengetahuan dan keterampilan yang sesuai (Super, 1990 dalam Rogers, dkk., 2018).

Salah satu permasalahan karier yang dialami siswa Sekolah Menengah Atas adalah masih belum memahami potensi diri, sehingga masih kebingungan dalam menentukan studi lanjutan yang akan dipilihnya. Pentingnya perencanaan karier bagi siswa SMA agar siswa memiliki gambaran mengenai masa depannya dan meminimalisir kebingungan dalam menentukan studi lanjutannya nanti. Hal ini sejalan dengan hasil studi yang dilakukan oleh Budiamin (2002) di Kabupaten 
Bandung yaitu sebanyak $90 \%$ siswa menyatakan masih bingung dalam memilih karier (studi lanjut) di masa depan dan $70 \%$ siswa menyatakan rencana masa depan tergantung pada orang tua.

Oleh karena itu untuk mengembangkan kemampuan dalam merencanakan karier siswa, maka perlu untuk melaksanakan bimbingan karier di sekolah. Bimbingan karier yang diberikan dapat berupa informasi mengenai sekolah lanjutan, informasi mengenai pekerjaan yang sesuai dengan perkembangan zaman, dan bimbingan agar siswa dapat mengenali potensi dan minatnya.

\section{PEMBAHASAN}

\section{Bimbingan Karier}

Perkembangan karier merupakan bagian integral dari perkembangan individu (Crites, dalam Partino, 2006). Casto (dalam Partino, 2006) menegaskan perkembangan karier sebagai proses yang terus menerus, mencakup aspek perencanaan dan strategi memilih karier berdasarkan informasi tentang diri sendiri, dunia kerja, dan tindakan yang diambil dimasa depan.
Karier merupakan suatu keseluruhan kehidupan seseorang dalam perwujudan diri untuk menjalani hidup dan mencapai tujuan. Untuk mencapai tujuan tersebut, individu harus memiliki kekuatan seperti penguasaan kemampuan dan aspek yang menunjang kesuksesan karier. Perencanaan karier merupakan salah satu aspek yang paling penting dalam perkembangan karier individu. Kecakapan dalam mengambil keputusan merupakan tujuan utama dalam perencanaan karier yang harus ditempuh oleh setiap individu (Atmaja, 2014).

Yusuf (2010) memaparkan bahwa siswa pada jenjang Sekolah Menengah Atas tergolong pada fase perkembangan remaja, di mana masa remaja sangat kompleks sehingga memerlukan bantuan dan bimbingan yang lebih komprehensif. Remaja dituntut untuk memenuhi tugasnya dalam memilih dan menentukan karier.

Piaget (dalam Suherman, 2013) menyatakan bahwa kognitif pada masa remaja masuk pada tahap proses berfikir formal. Remaja sudah dapat berpikir secara abstrak dan logis untuk membuat rencana kariernya, menggunakan informasi karier yang ada untuk 
memprediksikan dampak dari pengambilan keputusan karier. Oleh karena itu, bimbingan dan konseling karier remaja lebih mengutamakan tentang pemahaman dirinya dan lingkungan sekitar dalam membuat dan menentukan rencana pilihan kariernya.

Bimbingan karier merupakan upaya bantuan terhadap individu agar dapat mengenal dan memahami dirinya, mengenal dunia kerjanya, mengembangkan masa depannya sesuai dengan bentuk kehidupan yang diharapkan. Dengan layanan bimbingan karier, individu mampu menentukan dan mengambil keputusan secara tepat dan bertanggungjawab atas keputusan yang diambilnya sehingga mereka mampu mewujudkan dirinya secara bermakna (Yusuf \& Nurihsan, 2016).

Suherman (2013) memaparkan bahwa bimbingan karier adalah aktivitas-aktivitas dan programprogram yang membantu individu untuk mengasimilasikan dan mengintegrasikan pengetahuan, pengalaman, dan apresiasi yang berkaitan dengan: (1) pengenalan diri; (2) pemahaman/ pengenalan terhadap kerja masyarakat dan faktor-faktor yang mempengaruhi perubahannya; kesadaran akan waktu luang; (4) pemahaman akan perlu dan banyaknya faktor yang harus dipertimbangkan dalam perencanaan karier; pemahaman terhadap informasi dan keterampilan yang diperlukan untuk mencapai pemenuhan diri dalam pekerjaan dan waktu luang; (6) mempelajari dan menerapkan proses pengambilan keputusan karier.

Layanan atau program bimbingan karier di Indonesia seharusnya memahami dan memenuhi kebutuhankebutuhan siswa dalam perkembangan karier sehingga memiliki keterampilan karier pada saat meninggalkan bangku sekolah. Hoyt (dalam Lestari, 2017) mengemukakan ada empat kebutuhan utama yaitu: (1) Merencanakan pendidikan pasca sekolah menengah yang berorientasi karier; Memperoleh keterampilan umum dalam cakap kerja, adaptasi kerja, dan peningkatan kerja sehingga mampu mengikuti perubahan dunia kerja setelah dewasa; (3) Penekanan pentingnya nilai-nilai kerja; (4) Merencanakan caracara menyibukkan diri dalam pekerjaan sebagai bagian dari keseluruhan perkembangan karier. 


\section{Perencanaan Karier}

Perencanaan karier dapat diartikan sebagai kegiatan pencarian informasi yang dilakukan oleh individu dan seberapa banyak mereka mengetahui tentang berbagai aspek pekerjaan. Aspek-aspek perencanaan karier diantaranya: (1) belajar tentang informasi pekerjaan; (2) berbicara dengan orang dewasa tentang rencana studi lanjutan; (3) mengikuti kursus yang akan membantu seseorang membuat keputusan karier; berpartisipasi dalam kegiatan ekstrakurikuler atau bekerja part-time; (5) memperoleh pendidikan dan latihan untuk pekerjaan. Diskusi tentang rencana masa depan, termasuk pemilihan perguruan tinggi berkontribusi pada perencanaan karier (Super, dalam Sharf, 2010)

Perencanaan karier merupakan proses pencapaian tujuan karier individu, yang ditandai dengan adanya tujuan yang jelas setelah menyelesaikan pendidikan, cita-cita yang jelas terhadap pekerjaan, dorongan untuk maju dalam bidang pendidikan dan pekerjaan yang dicita-citakan, persepsi yang realistis terhadap diri dan lingkungan, kemampuan mengelompokkan pekerjaan yang diminati, memberikan penghargaan yang positif terhadap pekerjaan dan nilai-nilai, kemandirian dalam proses pengambilan keputusan, kematangan dalam hal mengambil keputusan, dan menunjukkan cara-cara realistis dalam mencapai cita-cita pekerjaan (Adiputra, 2015).

Dari penjelasan yang telah diuraikan dapat disimpulkan bahwa perencanaan karier adalah tahap dimana individu mulai memikirkan masa depannya, seperti karier yang akan dipilihnya hingga tujuan hidupnya. Perencanaan karier sebaiknya didukung oleh orang-orang disekitar, seperti orang tua, keluarga serta guru bimbingan dan konseling. Dalam membuat perencanaan karier, siswa mulai mencari informasi-informasi mengenai karier yang akan dipilihnya, sehingga siswa dapat mempersiapkan dirinya dengan baik.

Hasil dari perencanaan itu sendiri ialah tentang sesuatu yang dipilih secara sadar dari sejumlah alternatif yang dapat dipilih. Kunci dari perencanaan yang baik dan keputusan yang bijaksana terletak dalam pengolahan informasi tentang diri sendiri dan tentang lingkungan hidupnya. Dengan kata lain 
hanyalah orang muda yang memiliki informasi yang relevan dan menafsirkan maknanya bagi dirinya sendiri, dapat membuat pilihan-pilihan yang dapat dipertanggungjawabkan (Winkel \& Hastuti, 2012).

Perencanaan karier dapat dilakukan dengan beberapa cara. Adapun salah satunya dengan melakukan tes MBTI (Myers Brigg Type Indicator). MBTI dibuat dengan merujuk pada teori kepribadian dari Carl Gustav Jung. Inventori ini pertama kali dikenalkan oleh Katharine Cook Briggs dan Isabel Briggs Myers. MBTI analisisnya menggambarkan 16 tipe kepribadian, saran pengembangan, karier yang cocok untuk ditekuni dan pasangan tipe kepribadian yang cocok. MBTI dibangun berdasarkan pada empat dimensi yang disusun berlawanan. Inventori MBTI tidak disusun dengan jawaban benar salah, akan tetapi responden harus menjawab sesuai dengan keadaan dirinya. MBTI cocok digunakan bagi remaja usia sekolah menengah atas, informasi yang diperoleh dapat digunakan sebagai pertimbangan untuk merencanakan arah karier dimasa datang (Susanto \& Mudaim, 2017).
Dalam merencanakan karier, siswa juga membutuhkan dukungan dan masukan dari orang terdekatnya. Penelitian yang dilakukan oleh Lim \& You (2017) menunjukkan bahwa para orang tua perlu untuk membangkitkan semangat anak-anak mereka dan menyediakan lingkungan untuk mengeksplorasi jalur karier mereka dengan bijak dalam menghadapi situasi perubahan masyarakat yang begitu cepat seperti sekarang ini. Untuk mendorong persiapan karier siswa, tidak hanya dengan dukungan, namun para orang tua juga dapat membantu siswa untuk memilih karier dengan percaya diri berdasarkan nilai-nilai dan bakat sehingga meningkatkan harga diri anak mereka.

\section{SIMPULAN}

Bimbingan karier diperlukan agar siswa dapat merencanakan karier dengan tepat sesuai dengan potensi dan kemampuan yang dimilikinya. Bagi siswa SMA, pemilihan karier dimulai dengan mengenali potensi dirinya dan mencari informasi mengenai jurusan/ program studi yang tepat sesuai dengan minat dan potensi yang dimilikinya. Prospek karier dimasa yang akan datang 
juga dapat menjadi faktor pertimbangan bagi siswa dalam memilih studi lanjutan. Siswa yang dapat merencanakan kariernya dengan baik ditandai dengan siswa mulai mengenali dan mengembangkan potensi yang dimilikinya, serta memikirkan kehidupan mereka di masa yang akan datang. Dengan perencanaan yang matang, diharapkan nantinya mereka dapat memberikan kontribusi terhadap kehidupan berdasarkan kemampuan yang dimiliki. Sedangkan siswa yang kurang persiapan dalam merencanakan karier ditandai dengan siswa cenderung belum memiliki gambaran masa depannya seperti apa, sehingga enggan untuk mencari informasi mengenai jurusan yang sesuai dengan potensi yang dimilikinya. Hal ini bisa berakibat salah ambil jurusan bahkan tidak melanjutkan pendidikan ke jenjang yang lebih tinggi, dan pada akhirnya menyebabkan meningkatnya angka pengangguran. Dampak dari salah mengambil jurusan adalah tidak produktifnya seseorang dalam bekerja karena karier yang dijalaninya tidak sesuai dengan potensi yang dimilikinya. Individu cenderung akan setengah hati dalam bekerja, dan mengakibatkan kurangnya produktivitas dalam melakukan pekerjaannya. Untuk itu, perlunya bimbingan karier di sekolah untuk meminimalisir dampakdampak yang akan terjadi, dan diharapkan layanan bimbingan karier yang diberikan dapat membantu siswa dalam perkembangan kariernya secara optimal.

\section{REFERENSI}

Adiputra, S. (2015). Penggunaan Teknik Modeling terhadap Perencanaan Karier Siswa. Jurnal Fokus Konseling 1(1), hlm. 45 56.

Atmaja, T.T. (2014). Upaya Meningkatkan Perencanaan Karier Siswa Melalui Bimbingan Karier dengan Penggunaan Media Modul. Psikopedagogia 3(2), hlm. 58-67.

Budiamin, A. (2002). Manajemen Bimbingan Karier pada SMU Negeri di Kabupaten Bandung. Jurnal Psikologi Pendidikan dan Bimbingan 2, hlm. 259-266.

Lestari, I. (2017). Meningkatkan Kematangan Karier Remaja melalui Bimbingan Karier Berbasis Life Skill. Jurnal Konseling GUSJIGANG 3(1), hlm. 17 - 27.

Lim, S.A \& You, S. (2017). Long-term Effect of Parents' Suport on 
Adolescents Career Maturity.

Journal of Career Development 20(10), hlm. 1-14.

Partino, H.R. (2006). Kematangan

Karier Siswa

SMA. Psikologika 21(11), hlm.37-

50.

Pratama, B.D. \& Suharnan. (2014). Hubungan antara Konsep Diri dan Internal Locus of Control dengan Kematangan Karier Siswa SMA. Persona, Jurnal Psikologi Indonesia 3(3), hlm. 213-222.

Rogers, dkk. (2018). Parent and Adolescent Perceptions of Adolescent Career Development Tasks and Vocational Identity. Journal of Career Development 45(1), hlm. 34-49.

Sharf, R. (2010). Applying Career Development Theory of Counseling. USA: Cengage Learning.

Suherman, U. (2013). Bimbingan dan Konseling Karier; Sepanjang Rentang Kehidupan. Bandung: Rizqi Press.

Sukardi, D. K. (1989). Bimbingan Karier di Sekolah-sekolah. Jakarta: Ghalia Indonesia.
Susanto, E \& Mudaim (2017). Pengembangan Inventori MBTI sebagai Alternatif Instrumen Pengukuran Tipe Kepribadian. Indonesian Journal of Educational Counseling 1(1); hlm. 41-52.

Winkel, W. S \& Hastuti, S. (2012). Bimbingan dan Konseling di Institusi Pendidikan. Yogyakarta: Media Abadi.

Xiao J.J., dkk. (2016). Career Preparation of High School Students: A Multi-Country Study. Youth \& Society 1-23.

Xu, H. \& Lee, J.C. (2017). Exploring the Contextual Influences on Adolescent Career Identity Formation: A Qualitative Study of Hong Kong Secondary Students . Journal of Career Development $X X(X)$, hlm. 116.

Yusuf, $\quad$ S.(2010). Psikologi Perkembangan Anak \& Remaja. Bandung: PT Remaja Rosdakarya. Yusuf, S. \& Nurihsan, A.J. (2016). Landasan Bimbingan dan Konseling. Bandung: PT. Remaja Rosdakarya. 